(CAUTHE) Annual Conference 2018

Full Paper No. 59

\title{
CLIMATE CHANGE ADAPTATION IN THE COASTAL TOURISM HOTEL SECTOR: THE CASE OF SIHANOUKVILLE, CAMBODIA
}

\author{
Tinat Nhep ${ }^{1}$, Christian Schott ${ }^{2}$ and Mondher Sahli ${ }^{3}$
}

\begin{abstract}
Cambodia is a country, which has seen very rapid tourism development over the last decade, while also being identified as very vulnerable to the impacts of climate change (CC) by several key international agencies. This paper takes the form of a climate change-focused case study of the coastal tourism hotel sector in Cambodia's Sihanoukville. It is based on semi-structured interviews with hotel managers and field observations. The paper's aims are sequential and start by initially examining to what extent Sihanoukville's hotel sector is vulnerable to $\mathrm{CC}$, which is followed by an analysis of the hotel sector's adaptation. Finally the type and nature of adaption is critically compared and contrasted by star rating and location relative to the seashore. Some interesting findings emerge that highlight paradoxes in the context of the vulnerabilityadaptation dynamic. Future research should investigate the barriers and critical success factors (SF) for CC adaptation (CCA), as these factors will provide valuable insights into the vulnerability-adaptation dynamic in Sihanoukville, thereby contributing to the UN's Sustainable Development Goal (SDG) 13 Climate Action ${ }^{4}$.
\end{abstract}

Keywords: climate change vulnerability; climate change adaptation; coastal tourism; hotel; Cambodia

\section{INTRODUCTION}

Following the collapse of the Khmer Rouge regime in 1979 Cambodia's economy grew slowly but steadily especially after the 1991 Paris Peace Accord. Cambodia's economy depends on four main sectors: agriculture, tourism, garment manufacturing and construction. Cambodia's tourism has grown very rapidly over the last decade, with a near doubling in visitor arrivals over the four year period from 2011 (2.8 million) to 2015 (4.7 million) (UNWTO, 2016). In 2020, the projection is 7 million inbound tourists that will generate USD 5 billion and 80,000 jobs (RGC, 2012). Cambodia's Sihanoukville is one of the newly emergent coastal resorts in Asia (Ong \& Smith, 2014). Located on the Gulf of Thailand, Sihanoukville is $230 \mathrm{~km}$ southwest of Phnom Penh, the Cambodian capital. Sihanoukville is the hub of coastal tourism and beach and sea activities along the major beaches along with scuba diving, snorkeling and fishing from the coastal islands of Sihanoukville are the major tourism activities (Ong \& Smith, 2014).

Rapid tourism growth of developing countries like Cambodia is often accompanied by significant challenges, one of which is CC. Developing countries are more vulnerable and have weak adaptive capacities for CC responses (Smit \& Wandel, 2006). The UN (2017) classified Cambodia as one the least developed countries (LCDs) and the UN's criteria for LCDs identifies that structural vulnerability to rapid economic and environmental changes is high for these countries. This vulnerability contributes to Cambodia being listed as one of the world's ten countries with the highest exposure to natural hazards and CC (World Risk Report, 2012). Indeed, it is the most vulnerable nation to CC in the South East Asian region (Yusuf \& Francisco, 2009) and loses 3.1\% of its annual GDP to extreme events (Harmeling \& Eckstein, 2013). Its coastal zone is particularly vulnerable to CC (MOE, GEF, \& UNEP, 2015) because of sea level rise (SLR), floods, drought, increased storm frequency, increased temperature and erratic rainfall. All of these have already affected the living conditions, agricultural activities, other production systems, infrastructure, coastline erosion, and ecological system in the province (MOE, GEF, \& UNEP, 2015).

Cambodia applies "no-regrets" adaptation options at national level (RGC, 2006). This approach places an emphasis on maximizing positive and minimizing negative impacts of nature based adaptation strategies and options (Rizvi et al., 2014). Cambodia's "no-regrets" adaptation options can be divided into three categories: (i) capacity building/training (ii) awareness raising/education, and (iii) infrastructure development (RGC, 2006). Second, Cambodia has enacted various legal documents related to CC shown in Appendix 1. According to MOE, GEF, \& UNEP (2015) Sihanoukville's vulnerability requires appropriate and urgent adaptation and Dzoga \& Koske (2014)

\footnotetext{
${ }^{1} \mathrm{PhD}$ Candidate, School of Management, Victoria University of Wellington, New Zealand.

${ }^{2}$ Senior Lecturer, School of Management, Victoria University of Wellington, New Zealand

${ }^{3}$ Associate Professor, School of Management, Victoria University of Wellington, New Zealand

${ }^{4}$ United Nations Sustainable Development Goals
} 
suggest that hotels located by the beach in particular need to develop strategies to deal with climate vulnerability so as to sustain the many economic benefits offered by tourism. As such the paper contributes to the United Nations 2030 Agenda for Sustainable Development as articulated in the Sustainable Development Goals. The paper addresses Goal 13 Climate Action and in particular targets 1 (Strengthen resilience and adaptive capacity to climate-related hazards and natural disasters in all countries) and 3 (Improve education, awareness-raising and human and institutional capacity on climate change mitigation, adaptation, impact reduction and early warning).

The paper's aims are sequential. Initially the extent to which Sihanoukville's hotel sector is vulnerable to CC is examined from the perspective of hotel manager. Subsequently, the hotel sector's adaptation measures are analyzed before the type and nature of adaption actions is critically compared and contrasted by star rating and location relative to the seashore.

\section{LITERATURE REVIEW}

This section provides an overview of the relevant literature by highlighting the interrelationships between CC vulnerability and adaptation, as well as identifying the gaps in knowledge.

\section{Climate change vulnerability and adaptation}

$\mathrm{CC}$ is "a change in the state of the climate that can be identified (e.g. using statistical tests) by changes in the mean and/or the variability of its properties, and that persists for an extended period, typically decades or longer. It refers to any change in climate over time, whether due to natural variability or as a result of human activity" (IPCC, 2007, p.30). Whether for assessment or practice purpose, climate change adaptation is closely related to the concept of vulnerability (Smit \& Wandel, 2006). IPCC ${ }^{5}$ (2007) defines vulnerability as "the degree to which a system is susceptible to, and unable to cope with, adverse effects of $\mathrm{CC}$, including climate variability and extremes. Vulnerability is a function of the character, magnitude, and rate of $\mathrm{CC}$ and variation to which a system is exposed, the sensitivity and adaptive capacity of that system". The IPCC proceeds to define climate change adaptation (CCA) as "adjustment in natural or human systems in response to actual or expected climatic stimuli or their effects, which moderates harms or exploits beneficial opportunities" (p.6).

There are a variety of studies that have focused on vulnerability assessment in the context of climate change (Smit \& Wandel, 2006). For example, Moreno \& Becken (2009) assess vulnerability through social, economic, and environmental factors since these factors occur at local through to national scales. Developing countries, like Cambodia, have been identified as most vulnerable to CC and environmental risks include drinking water loss, drought, extreme temperature pattern, SLR, and economic vulnerability include beach loss and property damage from hurricanes (Carlton \& Jacobson, 2013).

However, access to information relevant to $\mathrm{CC}$ vulnerability has been insufficient both in urban and rural areas (Mukheibir \& Ziervogel, 2007) and identifying vulnerabilities for planning CCA requires enormous amounts of information (Moss et al., 2008). It is suggested that coastal tourism destination managers should first understand their vulnerability to climatic changes to formulate appropriate adaptation strategies and measures (Moreno \& Becken, 2009). This point is underscored by Walmsley (2012) who states that potential impacts need to be mentioned when discussing vulnerability to make sense of the need of adaptation. Following the same logic, this study initially identifies each hotel's level of vulnerability as reported by the hotel's manager before examining whether and what adaptation actions have been put in place.

\section{Vulnerability framework}

Vulnerability is conceptualized differently by various scholarly communities (Füssel, 2007). However, commonalities can be observed across the different conceptualizations, these are exposure, sensitivity and adaptive capacity (Binita, Shepherd, \& Gaither, 2015; O’Brien, Sygna, \& Haugen, 2004). The concept originated in IPPC reports and was later adopted by many CC researchers. Adopting IPPC's vulnerability definition and considering works by Becken et al. (2010) and Preston \& Stafford-Smith (2009), Figure 1 depicts a vulnerability framework.

\footnotetext{
${ }^{5}$ Intergovernmental Panel on Climate Change
} 
Figure 1: Vulnerability framework

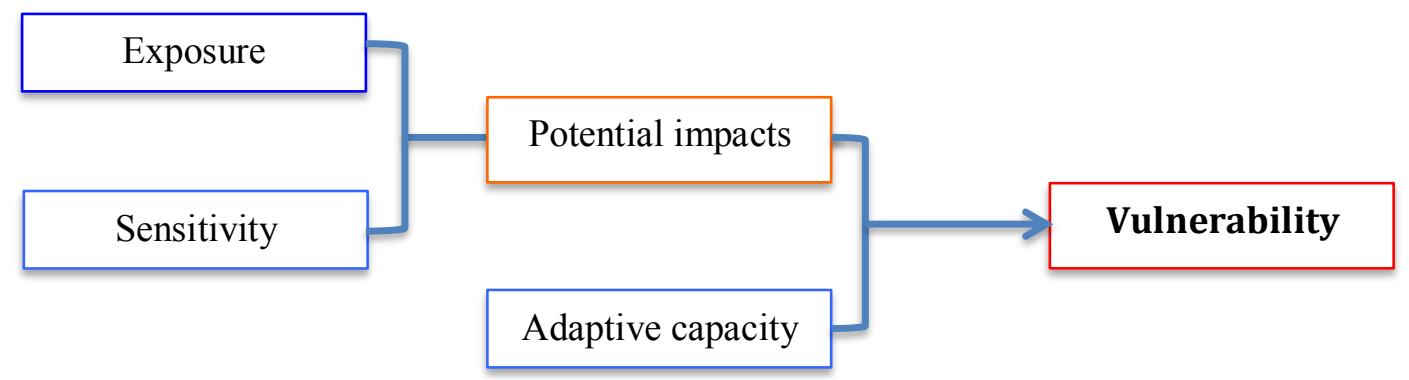

Source: adopted from IPPC (2007), Becken et al. (2010) and Preston \& Stafford-Smith (2009)

The measurement of CC vulnerability is typically related to a function of exposure to physical phenomena (e.g., droughts, floods), sensitivity to factors affecting the social environment, and the adaptive capacity of a particular unit for changing physical conditions (Binita et al., 2015). In the context of tourism, Becken et al. (2010) explain that exposure and sensitivity are regarded as the essential causes of the potential impact of a climatic condition, and adaptive capacity play a role as a mediator to reduce or increase vulnerability of a particular group, place or activity to those potential impacts.

\section{Coastal tourism and climate change adaptation}

According to Hall (2010), "coastal tourism embraces the full range of tourism, leisure, and recreationally oriented activities that take place in the coastal zone and the offshore coastal waters. These include coastal tourism development (accommodation, restaurants, food industry, and second homes) and the infrastructure supporting coastal development (e.g. retail businesses, marinas, and activity suppliers)" (p. 602). Coastal tourism is a growing sector due to both its participation and economic involvement (Moreno \& Becken, 2009). Coastal tourism establishes the main economic sector and source of employment for many communities, countries and regions globally (Moreno \& Becken, 2009).

Coastal and marine environments have been identified as being highly vulnerable and likely to be especially affected by CC (Walmsley, 2012; Moreno \& Amelung, 2009; IPCC, 2007). CC directly impacts on not only the physical, environmental and social resources important for tourism but also the convenience, perceptions and safety of participants (Moreno \& Amelung, 2009). As such adaptation cannot be avoided (Afroz \& Naser, 2014) because it reduces the risks of negative CC impacts (Jopp et al., 2013). Yet, research on tourism and adaptation faces limitations (Kaján \& Saarinen, 2013) and this relationship remains under-studied compared to many other sectors, especially in developing countries (Kaján \& Saarinen, 2013). Many impacts and activities remain fundamentally unexplored in relation to CC and coastal tourism (Moreno \& Amelung, 2009).

\section{Hotel sector and climate change adaptation}

Accommodation is the center of the tourism industry since it is an essential part of tourism supply (Poudel, 2013) and includes hotels, motels, vacation homes, vacation villages, caravans, etc. The hotel sector is the most important sub-sector in tourism because it has grown rapidly and hotel's mechanisms are well formulated for tourism (Dzoga \& Koske, 2014). However, the hotel sector is categorized as being affected by CC (Walmsley, 2012; Su, Hall, \& Ozanne, 2013) and highly vulnerable to climate change (Walmsley, 2012; Su, Hall, \& Ozanne, 2013). Due to hotel's inability to simply move from one location to another, unlike the tourist, hotels' adaptive capacity is weaker than other tourism businesses (Walmsley, 2012; WMO, UNEP \& WTO, 2008). Further, Hall (2010) points out that adaptation should be in hotel's interest due to competition, cost concerns and a wish to maintain tourism growth. As part of the adaptation concept the beach hotels could exploit the potential opportunities as well. For instance, Coles, Dinan, \& Warren (2016) explain that new designs, technologies and construction techniques offer opportunities for buildings to adapt to changing climate while simultaneously lessening their environmental load. Despite this the hotel sector has been observed to have a low level of implementation of CC responses (Su, Hall, \& Ozanne, 2013). 


\section{Adaptation frameworks}

Various authors, including Jopp et al. (2013) and Becken \& Hay (2007), discussed adaptation, however what they proposed was not sufficient for this research. In contrast, WMO, UNEP \& WTO (2008) provide a detailed adaptation framework for tourism and $\mathrm{CC}$ that includes distinctions between technical, managerial, policy, research and education measures as well as different tourism stakeholders. The study adopted this adaptation framework (Appendix 2). The framework provided an important contextualization and even conceptualization to the topic in Cambodia's and a developing country's context.

\section{METHODOLOGY}

Data were gathered from multiple sources during fieldwork in Cambodia between July 2016 and January 2017. In combination in-depth semi-structured interviews with hotel managers and key informants, informal site observations, and government reports allowed for a detailed picture of adaptation in Sihanoukville's hotel sector to be developed. This paper deals only with the interviews conducted with hotel managers. The data collection included two phases of pilot interviews to ensure that the questions were well understood and clearly targeted before the actual semistructured in-depth interviews took place. To provide consistent context during the interviews, definitions of CC, vulnerability and adaptation (stated in the previous page) were introduced prior to the interviews and re-introduced during the interviews. All participants were requested to contextualize answers based on those definitions.

First, to establish a measure of CC vulnerability participants were asked to respond on a five point Likert scale to this question: "To what extent is your hotel vulnerable to CC?". Then the researcher used the adapted vulnerability framework (Figure 1) to guide the answers. Second, hotel managers they were asked how their hotel had adapted to $\mathrm{CC}$ to overcome vulnerabilities. Then the researcher used the adaptation framework adopted from WMO, UNEP \& WTO (2008) (see the Appendix 2) to sort the responses into different adaptation domains. A total of 50 semistructured interviews were conducted in Sihanoukville; twelve interviews in English and 38 in Khmer. All interviews took place at the interviewees' offices and lasted one hour on average.

Amongst several characteristics that will be examined in the $\mathrm{PhD}$ thesis two were selected for comparative analysis for this conference paper:

- quality rating: budget, mid-scale, upscale and luxurious hotels

- location: at the mainland and along the beaches

These characteristics were selected because they may have a bearing on both vulnerability levels and adaptation measures. For instance, Su, Hall, \& Ozanne (2013) state that accommodation characteristics such as size, ownership, and location influence the application of green practices.

\section{FINDINGS}

\section{Vulnerability}

Irrespective of the ratings, Tables 1 and 2 indicate that over half of the participants explained that their hotels were slightly vulnerable to CC while about one third of them were moderately vulnerable. About $10 \%$ was vulnerable and equally $2 \%$ was very vulnerable and not vulnerable. The large majority (about $85 \%$ ) of the participants said their hotels were either slightly or moderately vulnerable.

The fieldwork enabled the classification of the hotels into two distinct areas: namely, on the mainland and along the beaches (their hotel structures or parts of it, were right on the beaches). Regardless of the locations, Tables 3 and 4 indicate that over half of the participants reported that their hotels were slightly vulnerable to $\mathrm{CC}$ while about one third of them were moderately vulnerable. About $10 \%$ was vulnerable and equally $2 \%$ was very vulnerable and not vulnerable. Again, the large majority (about 85\%) of the participants said their hotels were either slightly or moderately vulnerable.

It is interesting to note that the data for both ratings and location indicates that the majority of the participants agreed that their hotels were slightly and moderately vulnerable (85\%). This is reflected by the similar means and relative low standard deviations in Tables 2 and 4. 
(CAUTHE) Annual Conference 2018

Table 1: Star rating vs. vulnerability (in \%)

\begin{tabular}{|l|l|c|c|c|c|c|}
\hline \multicolumn{2}{|c|}{} & \multicolumn{5}{|c|}{ The extent of the hotel's vulnerability to CC } \\
\cline { 3 - 7 } \multicolumn{2}{|c|}{} & $\begin{array}{c}\text { Not } \\
\text { vulnerable }\end{array}$ & $\begin{array}{c}\text { Slightly } \\
\text { vulnerable }\end{array}$ & $\begin{array}{c}\text { Moderately } \\
\text { vulnerable }\end{array}$ & $\begin{array}{c}\text { Very } \\
\text { Vulnerable } \\
\text { vulnerable }\end{array}$ \\
\hline \multirow{3}{*}{$\begin{array}{l}\text { The hotel star } \\
\text { rating }\end{array}$} & Budget $(\mathrm{n}=10)$ & & 50 & 40.0 & 10 & \\
\cline { 2 - 7 } & Mid-scale $(\mathrm{n}=19)$ & & 57.9 & 31.6 & 5.3 & 5.3 \\
\cline { 2 - 7 } & Upscale $(\mathrm{n}=17)$ & 5.9 & 41.2 & 35.3 & 17.6 & \\
\cline { 2 - 7 } & Luxurious (n=3) & & 100 & & & 2 \\
\hline \multicolumn{2}{|l|}{ Total } & 2 & 53.1 & 32.7 & 10.2 & 2 \\
\hline
\end{tabular}

Table 2: Star rating vs. vulnerability

\begin{tabular}{|l|c|c|c|}
\hline \multicolumn{4}{|c|}{ The extent of the hotel's vulnerability to CC } \\
\hline The hotel star rating & Mean & Std. Deviation & $\mathrm{N}$ \\
\hline Budget & 2.60 & .699 & 10 \\
\hline Mid-scale & 2.58 & .838 & 19 \\
\hline Upscale & 2.65 & .862 & 17 \\
\hline Luxurious & 2.00 & .000 & 3 \\
\hline Total & 2.57 & .791 & $49^{6}$ \\
\hline
\end{tabular}

Table 3: Location vs. vulnerability (in \%)

\begin{tabular}{|l|c|c|c|c|c|c|}
\hline \multicolumn{2}{|c|}{} & \multicolumn{5}{|c|}{ The extent of the hotel's vulnerability to CC } \\
\cline { 3 - 7 } \multicolumn{2}{|c|}{} & $\begin{array}{c}\text { Not } \\
\text { vulnerable }\end{array}$ & $\begin{array}{c}\text { Slightly } \\
\text { vulnerable }\end{array}$ & $\begin{array}{c}\text { Moderately } \\
\text { vulnerable }\end{array}$ & $\begin{array}{c}\text { Very } \\
\text { Vulnerable }\end{array}$ \\
vulnerable \\
\hline $\begin{array}{l}\text { The location of } \\
\text { hotel }\end{array}$ & At the mainland $(\mathrm{n}=34)$ & 2.9 & 64.7 & 29.4 & & 2.9 \\
\cline { 2 - 7 } & Along the beach $(\mathrm{n}=15)$ & & 26.7 & 40 & 33.3 & 2 \\
\hline \multicolumn{2}{|l|}{} & 2 & 53.1 & 32.7 & 10.2 & 2 \\
\hline
\end{tabular}

Table 4: Location vs. vulnerability

\begin{tabular}{|l|r|r|r|}
\hline \multicolumn{4}{|c|}{ The extent of the hotel's vulnerability to CC } \\
\hline The location of hotel & Mean & Std. Deviation & N \\
\hline At the mainland & 2.35 & .691 & 34 \\
\hline Along the beach & 3.07 & .799 & 15 \\
\hline Total & 2.57 & .791 & 49 \\
\hline
\end{tabular}

The respondents said that their hotels were both environmentally and socio-economically vulnerable. The hotels were environmentally vulnerable to prolonged drought/limited water, excessive rainfalls, and SLR/beach erosion, and socio-economically vulnerable to damages of infrastructures (from storm and storm surges) and widespread of diseases (resulted from the increased temperature and exposure to rain). Interestingly, excessive rainfall is the most challenging vulnerability for all hotels. MOE's (2002) report suggests that nationally, the rainfall increases over the baseline for 2025, 2050 and 2100 would be between 5 and 15\%, 5 and $23 \%$ and 3 and $35 \%$, respectively. In a broader perspective, $\mathrm{WRI}^{7}$, Oxfarm, \& UNEP (2011) in UN SDGs found that in developing countries 83 percent of private companies indicate that $\mathrm{CC}$ impacts pose a threat to their products or services.

Table 5 is a combination of the hoteliers' perspectives and existing data that provide some supports for the study's findings on the vulnerability, especially under the vulnerability framework indicated in Figure 1.

\footnotetext{
${ }^{6} \mathrm{~N}=49$ because one data was missing; one participant forgot to rate the vulnerability

${ }^{7}$ World Resource Institute
} 
Table 5: Combination of hoteliers' perspectives and existing data on vulnerability in SHV

\begin{tabular}{|c|c|c|c|c|}
\hline \\
\hline \multirow{3}{*}{\multicolumn{2}{|c|}{ Hotel characteristics }} & \multicolumn{3}{|c|}{ Vulnerability } \\
\hline & & Exposure & Sensitivity & \multirow{2}{*}{ Adaptive capacity } \\
\hline & & \multicolumn{2}{|c|}{ Potential impacts } & \\
\hline \multirow[t]{5}{*}{ Star rating } & & & & \\
\hline & Budget & $\begin{array}{l}\text { More vulnerable to prolonged } \\
\text { drought/limited water, excessive }\end{array}$ & \multirow{4}{*}{$\begin{array}{l}\text { Population/accommodation } \\
\text { density } \\
\text { Production systems } \\
\text { Infrastructure } \\
\text { Ecosystems } \\
\text { Preparedness }\end{array}$} & \multirow{2}{*}{$\begin{array}{l}\text { Lower adaptive capacity due to low } \\
\text { economic income, education, awareness, } \\
\text { technology, infrastructure, and extension } \\
\text { services and networking }\end{array}$} \\
\hline & Mid-scale & $\begin{array}{l}\text { rainfalls, storm and storm surges } \\
\text { and rising temperature and } \\
\text { SLR/beach erosion }\end{array}$ & & \\
\hline & Upscale & \multirow{2}{*}{$\begin{array}{l}\text { Less vulnerable to prolonged } \\
\text { drought/limited water, excessive } \\
\text { rainfalls, storm and storm surges } \\
\text { and rising temperature and } \\
\text { SLR/beach erosion }\end{array}$} & & \multirow{2}{*}{$\begin{array}{l}\text { Higher adaptive capacity due to high } \\
\text { economic income, education, awareness } \\
\text { technology, infrastructure, and extension } \\
\text { services and networking }\end{array}$} \\
\hline & Luxurious & & & \\
\hline \multirow[t]{3}{*}{ Location } & & & & \\
\hline & At the mainland & $\begin{array}{l}\text { Prolonged drought/limited water, } \\
\text { excessive rainfalls, storm and storm } \\
\text { surges and rising temperature }\end{array}$ & $\begin{array}{l}\text { Population/accommodation } \\
\text { density } \\
\text { Production systems } \\
\text { Infrastructure } \\
\text { Preparedness }\end{array}$ & \multirow{2}{*}{$\begin{array}{l}\text { Depending on economic income, } \\
\text { education, awareness technology, } \\
\text { infrastructure, and extension services and } \\
\text { networking }\end{array}$} \\
\hline & Along the beaches & $\begin{array}{l}\text { Prolonged drought/limited water, } \\
\text { excessive rainfalls, storm and storm } \\
\text { surges and rising temperature and } \\
\text { SLR/beach erosion }\end{array}$ & $\begin{array}{l}\text { Population/accommodation } \\
\text { density } \\
\text { Production systems } \\
\text { Infrastructure } \\
\text { Ecosystems } \\
\text { Preparedness }\end{array}$ & \\
\hline
\end{tabular}




\section{Adaptation}

Despite the relatively low overall vulnerability reported in the above tables it is interesting to note that the number of adaptation measures and initiatives is large. Equally worth noting is that despite a lack of difference in the responses across the quality rating and location above, some notable trends are evident in the adaptation measures and initiatives report.

Adapting to drought/limited water: During drought periods all hoteliers significantly depended on the water supplied by Sihanoukville's city hall. However, because of the lack of reliability in the city water supply hotels adapted in two ways, by building water storage facilities and digging wells. In the most severe drought when all sources of water run out, the hoteliers bought water from mobile trucks. Due to the better networking and the nearer location (mostly in town), the upscale and luxurious and mainland hoteliers have quicker access to water than the lower standard hoteliers and the at-the-beach hotels. Paradoxically, despite this significant challenge to an essential resource, none of the hoteliers adapted by collecting rainwater.

Adapting to excessive rainfalls: Interviews also indicated that it was challenging for the hoteliers to adapt to excessive rainfalls. Adaptation examples included redesign and reconstruction of buildings such as roof, guttering, door, window and other building features exposed to rain while other hoteliers informed their staffs to take care of their health to avoid illness from the heavy rainfall and to be well prepared for helping the guests by checking or moving vulnerable objects. Learning from peers, prior to running the businesses, a few new hoteliers constructed their buildings adaptable to this vulnerability by building stronger structures and installing insulators, solar panels... etc. Only the upscale and luxurious hotel operators made mega changes on the hotel buildings such as reconstructing their connecting drainage systems for better rainwater flows.

Adapting to SLR/beach erosion: The hotels that were located on the mainland were not vulnerable to SLR/beach erosion while those that were along the beaches experienced this vulnerability. Interestingly, adaptation to $\mathrm{SLR} /$ beach erosion by those hoteliers was minimal and at an individual level despite their vulnerable locations. After the sands were washed away, the hoteliers used human labor, particularly their staffs to bring back dozen of sand gabions to refill the affected areas. They repeated such action from year to year. Field observations found that some hoteliers instituted seawall barriers as part of their adaptation measure and some hoteliers at the beaches planted mangrove and other species that act as wave protection. Besides, Dzoga \& Koske (2014) believe that planting and conserving mangrove and other species is one of the adaptation strategies because it aims at establishing barriers in coastal areas to resolve storms, and harnessing rainwaters to offset water shortfall.

Adapting to storm and storm surges: Storms or wind contractions occur frequently at the coast. The hoteliers on the coast adapted by redesigning and reconstructing the buildings by making stronger roofs, instituting retaining walls... etc., informing staffs to take care of their safety and to be well prepared (check or move vulnerable objects) for helping the guests, and repairing their hotel buildings after the events. Some planted the mangroves and other species in their premises help balance strengths of storms.

Adapting to increased temperature: The highest recorded temperature mentioned by the participants was 40 degrees but with high humidity. All hotels were reported to be vulnerable to it. Air conditioning was the most common method to respond while other measures were also mentioned: restructuring buildings especially roof overhangs, building hotels with thatched roof, installing insulation and spraying water, especially at night time (Note that spraying water could cool down the ground and rooftop areas. Once the guests arrive, they feel less hot. Thus, they do not consume much energy in the hotels).

Other forms of adaptation were educating, training, creating better mechanisms to receive and disseminate CC information and formulating short and long-term adaptation plans; for detailed findings and classification into the five adaptation domains please see the adopted WMO, UNEP \& WTO (2008) framework in Appendix 2. 


\section{DISCUSSION}

Due to its high structural vulnerability to economic and environmental shocks outlined in UN SDGs (2017), LCD or developing countries like Cambodia exhibit various forms of CC vulnerabilities. Coastal tourism is one of the important sectors of Cambodia's recent economic development, but also highly vulnerable to CC. Both the lack as well as the oversupply of rain is one of the most pronounced challenges highlighted by respondents. This may be true for most tropical countries like Cambodia where it receives six-month rains annually. It was the same note in the MOE's (2002) report. Although literature indicated that Cambodia as well as Sihanoukville is very vulnerable to $\mathrm{CC}$, most participants perceived that their hotels are slightly and moderately vulnerable. There are possible explanations: First, the participants were asked to rate the overall vulnerability, not individual susceptibility. Rating individual vulnerability might produce different results. For instance, their locations must influence the vulnerability if they were asked to rate the vulnerability in terms of SLR/beach erosion. Clearly, the mainland hoteliers must rate it (1) Not vulnerable at all while the along-the-beach hoteliers must rate it differently depending on their perceptions and other factors. The upscale and luxurious hoteliers might rate storm and storm surges as lower vulnerability due to sufficient resources while the budget and mid-scale hoteliers may rate it higher due to their low adaptive capacity. In terms of drought/water deficit, the mainland hoteliers may rate their vulnerability lower than the at-the-beach hotels because the former have quicker access to the water due their nearer location (mostly in town). Well water of the along-the-beach hotels has low quality (saltier due to saline intrusion) than that of the mainland hoteliers so the former would rate their vulnerability higher. For rains and rising temperature, irrespective of the location and star rating, the participants likely perceive similar or the same vulnerability, because rains and increased temperature spread across the city and share equal affects.

Second, the participants felt that their hotels might not have experienced serious CC impacts compared to other neighboring countries or their countries of origins (some of them were foreigners). Third, they rated the vulnerability based on the effects of occupancy rate. As long as the guests keep coming, their hotel's vulnerability was rated as low. Some guests came and sat in casinos. They were not much affected by the CC. One participant said, "It's hard one to say, you know a lot of tourists come to this time sit in the casinos, they don't go to the beach ..." $\mathrm{H} 15 \mathrm{~A}^{8}$. The second added, "I think also it depends on the kind of tourism because I think there is a lot of gambling tourists. I think they don't care about it as long as they have casinos." H34A. This does not reflect the true vulnerability of CC.

Fourth, they already strongly adapted to CC. For example, almost all hoteliers constructed water storage and dug up the water (digging a well costs around 10,000USD at the mainland and 20,000USD at the islands). For some luxurious hoteliers, they instituted seawalls and initiated clear programs for CCA. Third, although Cambodia's adaptation is low in general, fieldwork saw that are a number of adaptations in place initiated by the DPs. The initiatives included capacity building, planting conserving and re-planting mangroves in huge areas and constructing coastal dams. UN SDGs (2017) also indicates that number of LCDs are receiving amount of support, including finance, technology and capacity building for climate change-related planning and management. In addition to observations and evidence in Appendix-1, supporting informal interviews with governmental officials confirmed that despite insufficiency, these supports were available to Cambodia and Sihnaoukville. These initiatives may indirectly benefit the hotel sector. Nevertheless, to have clear evidence to what extent the hotel sector is vulnerable to $\mathrm{CC}$, a scientific investigation is recommended.

Appendix 2 shows various forms of adaptations. Overall, the budget and mid-scale hoteliers did not fully adapt to $\mathrm{CC}$ while the upscale and luxurious hoteliers had better and diversified adaptations. This suggests that the latter group may have had more access to knowledge and resources such as finance, human resources and networking. Smaller or family-oriented hoteliers were likely to be slightly adapting to CC due to their limited resources. Mowforth \& Munt (1998) support the claim that small and medium accommodations have less capital resources or less effective internal structural arrangement to perform the environmental management.

\footnotetext{
${ }^{8}$ Hotel 15, first interviewee (some interviews were participated by more than one interviewees)
} 
Overall, the upscale and luxurious hoteliers invested more in adaptations. For example, the fieldwork found that some instituted seawall barriers while none of the budget and mid-scale hoteliers had this initiative. This was costly adaptation. The higher standard hoteliers redesigned and reconstructed their places for better adapting to the rains, storms and the increased temperature while hoteliers on the lower end of the quality ranking constructed hotel foundations and others just temporarily for rainy and stormy seasons. One upscale hotelier explained, "we are ready because we are building ourselves in European standard. Climate cannot hurt us, not internal and not external to the building..." H449. Buildings play multiple roles in the global response to CC. New designs, technologies and construction techniques offer opportunities for buildings to adapt to changing climate while simultaneously lessening their environmental load (Coles, Dinan, \& Warren, 2016).

Generally, the upscale and luxurious often had good mechanism for information flow. Due to their longer-term vision, the upscale and luxurious hoteliers tended to formulate both short and long term adaptation plans. In contrast, the budget or low standard hoteliers constrained in receiving externally and sharing information internally. One smaller hotel participant complained, "My receptionists received information externally, but they just forgot to share it widely." H31. For example, they had little interactions/networking with the authority. They likely had neither short nor long term plans. They were mostly profit-oriented with short visions for adaptation. Chan (2011) and Kasim (2009) support that large, chain, and affiliated hotels tend to have better environmental knowledge and implementation. Authors, Mensah (2007) and Mowforth \& Munt (1998), argue that the bigger the hotels the more proactive and committed to environmental management. Horobin \& Long (1996) add that small tourist hotels have insufficient practical knowledge and steps to tackle the environmental issues. Maybe there are less expensive options for lower quality hotels (e.g. rainwater collection tanks, spaying water...etc.) but they did not access to and employ them. This may be due to lack of awareness.

The geographic locations influenced the adaptation measures by the hoteliers. This factor (location) may explain the relatively good correlation between vulnerability and adaptation measure. Along-the-beach hoteliers must additionally adapt to SLR/beach erosion while the mainland hoteliers do not have the same incentive. For example, the along-the-beach hoteliers built seawalls, employed human labor to bring sand gabions to refill the affected areas and planted mangrove forest. However, both locations (at the mainland and along the beaches) were similarly vulnerable to the excessive rainfall, prolonged drought, increased temperature, and drought/water insufficiency, thus leading to no different adaptation measures. In the same adaptation responses, the interviewees indicated that they redesigned and reconstructed their hotel infrastructures such as roof, window and door to respond to the rain, storm and rising temperature. In the meantime, they built water storage/tanks and dug wells to respond to the drought and water deficit. Additionally, they informed the staffs and guests about the possible impacts. For future vision, they also formulated short and long-term adaptation plans.

Although Cambodia has a clear policy mandate for the MOT and $\mathrm{MOE}^{10}$ (see the Appendix $1 \& 2$ ) to address tourism and $\mathrm{CC}$ issues, neither its tourism principles, nor its $\mathrm{CC}$ strategies are fully incorporated. Cambodia has no tourism strategy or policy that directly targets the CC vulnerability to tourism (MOT, 2010). In the hotel sector, the government and local authority were likely aware that the budget and mid-scale hoteliers have low adaptive capacity. These hoteliers need urgent helps from the government. However, the government/authority did not fully help yet because of its own limited capacity as well. Necessary infrastructure (e.g., roads, electricity, clean water supply, etc.) is insufficient (UNWTO, 2014). In tourism some private investment projects have not developed to the current needs and the necessary quality of public and private human capital is low (RGC, 2010). Clearly, the budget and mid-scale hoteliers were not helped by the government/authority to adapt to CC. All hoteliers depended on their own resources to adapt.

Because private sector engagement (e.g. hotel businesses) is unable to substitute for critical need of public investment and policies, WRI, Oxfarm, \& UNEP (2011) in UN SDGs emphasize that it is the ultimate responsibility of the public sector to fill the needs of the critical CCA of the poor and vulnerable. Due to the unavailable resources and little helps from the government, the budget and mid-scale hoteliers likely have more barriers to CCA than the upscale and luxurious hoteliers. The elite resources might be one of the SFs allowing the

\footnotetext{
${ }^{9}$ Hotel 44

${ }^{10}$ Ministry of Tourism and Ministry of Environment
} 
upscale and luxurious hoteliers to adapt to the $\mathrm{CC}$. Obtaining $\mathrm{CC}$ information seemed to be a constraint for the small hotel operators due to their limited networking. To overcome the constraint, they should expand the network wider to external parties such as the local authority and DPs. This network might enable them get information (e.g. SLR, how to harness rainwater, etc.). The hoteliers should form a local association or committee to share information and other activities such as vulnerability and adaptations. Argument of this passage opens a new page for further research and discussion on the barriers to and SFs for CCA, for example in obtaining CC information, in the coastal tourism hotel sector.

\section{CONCLUSION}

The following conclusions can be drawn from the present study: First, developing countries like Cambodia are vulnerable to CC. Its main sectors such as tourism are also vulnerable. As the coastal zone is the most vulnerable, the coastal tourism is also susceptible. However, from the perspectives of the hoteliers, the hotel sector is slightly and moderately vulnerable regardless of the standard or location. The perception of vulnerability is low because the participants were asked to rate overall vulnerability; rating individual vulnerability (e.g. beach erosion, storm... etc.) might bring different vulnerability levels. Nevertheless, to have clear evidence to what extent the hotel sector at the coastal zone is vulnerable to $\mathrm{CC}$, a scientific investigation is recommended.

Second, developing countries or LCDs like Cambodia have weak adaptive capacity. Its main sectors such as tourism have also low adaptive capacity. However, private sector such as the coastal tourism hotel sector has different adaptive capacity. Due to the available resources such as finance and human capital, the higher standard hotel operators adapt to CC better than the lower standard hotel operators. The upscale and luxurious hoteliers have better networking locally, regionally and internationally while the budget and mid-scale hoteliers have limited networks. Except adapting to the SLR/beach erosion, the mainland hoteliers have similar adaptions to the on-the-beach hoteliers. Although the government/authority have limited capacity, the assistances from the government/authority and DPs might enhance adaptive capacity of the hoteliers whether their budget, mid-scale, upscale or luxurious and mainland or at-the-beach hotels.

Third, the upscale and luxurious hotel operators might have more SFs while the budget and mid-scale hotel operators may have more barriers. The mainland and at-the-beach hoteliers might have similar or same barriers and SFs. Future research should investigate the barriers and critical SFs for CCA, as these factors will provide valuable insights into the vulnerability-adaptation dynamic in Sihanoukville. Therefore, this $\mathrm{PhD}$ thesis will critically examine the barriers to and critical SFs for CCA of the hotel sector through different characteristics of the hotel and participants. The hotel characteristics include ownerships (foreign vs. local), business status (owner vs. leaseholders), size (big vs. small), and length of operation (long vs. short). The participant characteristics include ages (young vs. mid and old), education (educated vs. non-education), experience (long vs. short), position (high vs. low management) and length of stay in Sihanoukville (long vs. short). 


\section{APPENDIX}

Appendix 1: The climate change-related laws, legal documents and regulations

\begin{tabular}{|c|l|l|}
\hline Year & \multicolumn{1}{|c|}{ Legal Document/Action } & \multicolumn{1}{c|}{ Main Objective } \\
\hline 1994 & The Environmental Protection Law & $\begin{array}{l}\text { To serve as legal document which is partly supporting } \\
\text { the CC responses. }\end{array}$ \\
\hline 2095 & $\begin{array}{l}\text { United Nations Framework Convention on } \\
\text { Climate Change (UNFCC) }\end{array}$ & $\begin{array}{l}\text { To ratify the UNFCCC in 1995 and launched the first } \\
\text { CC project to help prepare the Cambodia's Initial } \\
\text { National Communication (UNDP/Global Environment } \\
\text { Fund, GEF) in 1999. }\end{array}$ \\
\hline 2010 & $\begin{array}{l}\text { The National Strategy Development Plan, } \\
\text { of Action to Climate Change (NAPA) }\end{array}$ & $\begin{array}{l}\text { These are “no-regrets" adaptation options that can be } \\
\text { divided into three categories: (i) capacity } \\
\text { building/training (ii) awareness raising/education, and } \\
\text { (iii) infrastructure development. }\end{array}$ \\
\hline 2010 & $\begin{array}{l}\text { The brief policy on Cambodia } \\
\text { Environmental and Climate Change }\end{array}$ & $\begin{array}{l}\text { It has been developed to support addressing the CC } \\
\text { impact of Cambodia. }\end{array}$ \\
\hline
\end{tabular}


Appendix 2: Adaptation framework of the hotels

\begin{tabular}{|c|c|c|c|c|c|c|c|c|}
\hline \multirow{2}{*}{$\begin{array}{c}\text { Type of } \\
\text { adaptation }\end{array}$} & \multirow[t]{2}{*}{ Vulnerability } & \multirow[t]{2}{*}{ Adaptation in hotel sector } & \multicolumn{4}{|c|}{ Star rating } & \multicolumn{2}{|c|}{ Location } \\
\hline & & & $\begin{array}{l}\text { Budget } \\
(10)\end{array}$ & $\begin{array}{l}\text { Mid- } \\
\text { scale (19) }\end{array}$ & $\begin{array}{l}\text { Upscale } \\
\quad(17)\end{array}$ & $\begin{array}{l}\text { Luxurious } \\
\text { (4) }\end{array}$ & $\begin{array}{l}\text { At the } \\
\text { mainland } \\
(34)\end{array}$ & $\begin{array}{l}\text { At the } \\
\text { beach } \\
(16)\end{array}$ \\
\hline \multirow{13}{*}{ Technical } & $\begin{array}{l}\text { Excessive rainfall/rainy } \\
\text { flooding }\end{array}$ & $\begin{array}{l}\text { Redesign and reconstruct their buildings such as } \\
\text { roof, door, window and others, and enlarge their } \\
\text { connecting drainage systems for better rainwater } \\
\text { flows. }\end{array}$ & $0^{11}$ & 0 & $1^{12}$ & 1 & 1 & 1 \\
\hline & \multirow{2}{*}{$\begin{array}{l}\text { Prolonged drought/limited } \\
\text { water }\end{array}$} & Build water storage/tanks & 1 & 1 & 1 & 1 & 1 & 1 \\
\hline & & Dig wells & 1 & 1 & 1 & 1 & 1 & 1 \\
\hline & \multirow[t]{2}{*}{ SLR/beach erosion } & $\begin{array}{l}\text { Use human labor, particularly their staff to bring } \\
\text { back dozen of sand gabions to refill to the } \\
\text { affected areas }\end{array}$ & 0 & 0 & 1 & 0 & 0 & 1 \\
\hline & & Institute seawall barriers & 0 & 0 & 1 & 1 & 0 & 1 \\
\hline & $\begin{array}{l}\text { Storm and storm surges } \\
\text { and SLR/beach erosion }\end{array}$ & $\begin{array}{l}\text { Plant mangrove (and others of its species) in } \\
\text { and near their premises help balance strengths } \\
\text { of storms, cool down the environment (provide } \\
\text { shades, and stabilize the beaches }\end{array}$ & 0 & 0 & 1 & 1 & 0 & 1 \\
\hline & All vulnerabilities & $\begin{array}{l}\text { Enable access to early warning equipment (e.g. } \\
\text { radios, TV...) }\end{array}$ & 1 & 1 & 1 & 1 & 1 & 1 \\
\hline & \multirow{2}{*}{ Increased temperature } & $\begin{array}{l}\text { Create short and long term plan for better } \\
\text { adaptation (e.g. installing solar panels). }\end{array}$ & 0 & 0 & 1 & 0 & 1 & 1 \\
\hline & & $\begin{array}{l}\text { Spray water to the ground and gardens at } \\
\text { nighttime }\end{array}$ & 0 & 0 & 1 & 1 & 1 & 0 \\
\hline & $\begin{array}{l}\text { Prolonged drought/limited } \\
\text { water }\end{array}$ & $\begin{array}{l}\text { Buy the truck-in water (mobile trucks carrying } \\
\text { water for sales) }\end{array}$ & 1 & 1 & 1 & 1 & 1 & 1 \\
\hline & \multirow[b]{2}{*}{ Increased temperature } & Use air conditioners & 1 & 1 & 1 & 1 & 1 & 1 \\
\hline & & $\begin{array}{l}\text { Restructure their buildings, and especially roof, } \\
\text { building hotels with thatching roof, and } \\
\text { installing insulators }\end{array}$ & 0 & 0 & 1 & 1 & 1 & 1 \\
\hline & & & & & & & & \\
\hline
\end{tabular}

${ }^{11} 0=$ No (The majority of them did not adapt)

${ }^{12} 1=$ Yes (The majority of them adapted) 
(CAUTHE) Annual Conference 2018

\begin{tabular}{|c|c|c|c|c|c|c|c|c|}
\hline \multirow[t]{2}{*}{ Managerial } & $\begin{array}{l}\text { All vulnerabilities } \\
\text { especially extreme } \\
\text { weather }\end{array}$ & $\begin{array}{l}\text { Decide to redirect clients away from impacted } \\
\text { areas (to alternative destination) }\end{array}$ & 1 & 1 & 1 & 1 & 1 & 1 \\
\hline & All vulnerabilities & $\begin{array}{l}\text { Create short and long term plan for better } \\
\text { adaptation }\end{array}$ & 0 & 0 & 1 & 1 & 1 & 1 \\
\hline Policy & $\begin{array}{l}\text { All vulnerabilities } \\
\text { especially storm surges, } \\
\text { rain and increased } \\
\text { temperature }\end{array}$ & $\begin{array}{l}\text { Comply with self-regulation }{ }^{13} \text { (e.g. building } \\
\text { design standards for force winds) }\end{array}$ & 1 & 1 & 1 & 1 & 1 & 1 \\
\hline & & & & & & & & \\
\hline \multirow[t]{2}{*}{ Research } & \multirow{2}{*}{ All vulnerabilities } & $\begin{array}{l}\text { Assess awareness of businesses and staff and } \\
\text { knowledge gaps }\end{array}$ & 0 & 0 & 1 & 1 & 1 & 1 \\
\hline & & $\begin{array}{l}\text { Create a program (e.g. Green Program) to be } \\
\text { self-sustained in changing climate }\end{array}$ & 0 & 0 & 1 & 1 & 1 & 1 \\
\hline \multirow{5}{*}{ Education } & \multirow{5}{*}{ All vulnerabilities } & $\begin{array}{l}\text { Inform staffs to save water, to take care their } \\
\text { health/illness such as cold and sunburn, and to } \\
\text { be well prepared (check or move vulnerable } \\
\text { objects) }\end{array}$ & 0 & 0 & 1 & 1 & 1 & 1 \\
\hline & & Provide guests with help such as first aids. & 0 & 0 & 1 & 1 & 1 & 1 \\
\hline & & $\begin{array}{l}\text { Join public education campaign (e.g. CC } \\
\text { awareness) }\end{array}$ & 1 & 1 & 1 & 1 & 1 & 1 \\
\hline & & $\begin{array}{l}\text { Receive CC trainings from other parties esp. the } \\
\text { authority }\end{array}$ & 1 & 1 & 1 & 1 & 1 & 1 \\
\hline & & Provide $\mathrm{CC}$ trainings to the staffs & 0 & 0 & 1 & 1 & 1 & 1 \\
\hline
\end{tabular}

[Adopted from WMO, UNEP \& WTO (2008)]

\footnotetext{
${ }^{13}$ Interviews revealed that the government and authority issued many policies for $\mathrm{CC}$ regulations in the constructions. But due to the high requirement and cost, almost all hotels did not obey standards by the government. Individual hotels used self-regulations for CCA.
} 


\section{REFERENCES}

Afroz, T., \& Naser, M. M. (2014). Adaptation to Climate Change in the International Climate Change Regime: Challenges and Responses. In Implementing Adaptation Strategies by Legal, Economic and Planning Instruments on Climate Change (pp. 1-11). Springer.

Becken, S., Butcher, G., Edmonds, J., Hendrikx, J., Hughey, K., Reisinger, A., \& Wilson, J. (2010). A nationallevel screening exercise to assess tourism's vulnerability to climate change (pp. 1-11). Land, Environment and People (LEaP). Retrieved from http://www.lincoln.ac.nz/PageFiles/6750/NationalScreeningOverview.pdf

Becken, S., \& Hay, J. E. (2007). Tourism and climate change: Risks and opportunities (Vol. 1). Multilingual Matters.

Carlton, S. J., \& Jacobson, S. K. (2013). Climate change and coastal environmental risk perceptions in Florida. Journal of Environmental Management, 130, 32-39.

Chan, E. S. (2011). Implementing environmental management systems in small-and medium-sized hotels: Obstacles. Journal of Hospitality \& Tourism Research, 35(1), 3-23.

Coles, T., Dinan, C., \& Warren, N. (2016). Carbon villains? Climate change responses among accommodation providers in historic premises. Journal of Heritage Tourism, 11(1), 25-42.

Dzoga, M. N., \& Koske, J. K. A. (2014). Assessment of Beach Hotels Adaptation Capacity to Climate Variability: The Case of Mombasa County, Kenya. International Journal of Humanities and Social Science, 4(3), 1-4.

Füssel, H.-M. (2007). Vulnerability: a generally applicable conceptual framework for climate change research. Global Environmental Change, 17(2), 155-167.

Hall, C. M. (2010). Changing paradigms and global change: From sustainable to steady-state tourism. Tourism Recreation Research, 35(2), 131-143.

Harmeling, S., \& Eckstein, D. (2013). Global climate risk index 2013: Who suffers most from extreme weather events? (pp. 1-27). Retrieved from https://germanwatch.org/en/download/7170.pdf

Horobin, H., \& Long, J. (1996). Sustainable tourism: the role of the small firm. International Journal of Contemporary Hospitality Management, 8(5), 15-19. https://doi.org/10.1108/09596119610126103

Jackie Ong, L. T., \& Smith, R. A. (2014). Perception and reality of managing sustainable coastal tourism in emerging destinations: the case of Sihanoukville, Cambodia. Journal of Sustainable Tourism, 22(2), 256278.

Jopp, R., DeLacy, T., Mair, J., \& Fluker, M. (2013). Using a regional tourism adaptation framework to determine climate change adaptation options for Victoria's Surf Coast. Asia Pacific Journal of Tourism Research, $18(1-2), 144-164$.

Kaján, E., \& Saarinen, J. (2013). Tourism, climate change and adaptation: A review. Current Issues in Tourism, $16(2), 167-195$.

Kasim, A. (2009). Managerial attitudes towards environmental management among small and medium hotels in Kuala Lumpur. Journal of Sustainable Tourism, 17(6), 709-725.

KC, B., Shepherd, J. M., \& Gaither, C. J. (2015). Climate change vulnerability assessment in Georgia. Applied Geography, 62, 62-74. https://doi.org/10.1016/j.apgeog.2015.04.007

Mensah, I. (2007). Environmental management and sustainable tourism development: The case of hotels in Greater Accra Region (GAR) of Ghana. Journal of Retail \& Leisure Property, 6(1), 15-22. https://doi.org/10.1057/palgrave.rlp.5100039

MOE, GEF, \& UNEP. (2015). Vulnerability Assessment to Climate Change in Preah Sihanouk Province. Phnom Penh, Cambodia.

Moreno, A., \& Amelung, B. (2009). Climate Change and Coastal \& Marine Tourism: Review and Analysis. Journal of Coastal Research, 1140-1144.

Moreno, A., \& Becken, S. (2009). A climate change vulnerability assessment methodology for coastal tourism. Journal of Sustainable Tourism, 17(4), 473-488.

Moss, R. H., Babiker, M., Brinkman, S., Calvo, E., Carter, T., Edmonds, J. A., ... Hibbard, K. (2008). Towards new scenarios for analysis of emissions, climate change, impacts, and response strategies. Pacific Northwest National Laboratory (PNNL), Richland, WA (US).

Mowforth, M., \& Munt, I. (1998). Tourism and sustainability: new tourism in the third world. London; New York: Routledge. 
Mukheibir, P., \& Ziervogel, G. (2007). Developing a Municipal Adaptation Plan (MAP) for climate change: the city of Cape Town. Environment and Urbanization, 19(1), 143-158.

O’Brien, K., Sygna, L., \& Haugen, J. E. (2004). Vulnerable or Resilient? A Multi-Scale Assessment of Climate Impacts and Vulnerability in Norway. Climatic Change, 64(1-2), 193-225. https://doi.org/10.1023/B:CLIM.0000024668.70143.80

Parry, M. L. (2007). Climate Change 2007: impacts, adaptation and vulnerability: contribution of Working Group II to the fourth assessment report of the Intergovernmental Panel on Climate Change (Vol. 4). Cambridge University Press.

Poudel, S. (2013). The influence of the accommodation sector on tourism development and its sustainability: Case Study: Strand Camping, Larsmo.

Preston, B., \& Stafford-Smith, M. (2009). Framing vulnerability and adaptive capacity assessment: Discussion paper (CSIRO Climate Adaptation Flagship Working paper No. 2.) (pp. 1-60). Australia. Retrieved from https://research.csiro.au/climate/wp-content/uploads/sites/54/2016/03/2_Working-Paper2_CAF_PDFStandard.pdf

Rizvi, A. R., Barrow, E., Zapata, F., Cordero, D., Podvin, K., Kutegeka, S., ... Adhikari, A. (2014). Ecosystem based Adaptation: Building on No Regret Adaptation Measures. Presented at the 20th session of the Conference of the Parties to the UNFCCC and the 10th session of the Conference of the Parties to the Kyoto Protocol, Lima, Peru: IUCN. Retrieved from http://cmsdata.iucn.org/downloads/iucn_eba_technical_paper_no_regret_actions_lima_cop_20.pdf

Royal Government of Cambodia. (2012). Tourism development strategic plan 2012-2020. Retrieved from

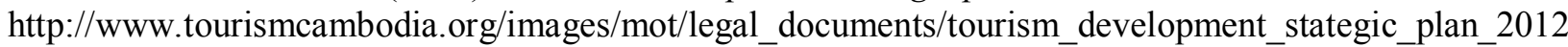
2020_english.pdf

Royal Government of Cambodia, RGC. (2010). National strategic development plan update 2009-2013. Phnom Penh, Cambodia. Retrieved from http://www.gafspfund.org/sites/gafspfund.org/files/Documents/Cambodia_6_of_16_STRATEGY_Nationa 1 Strategic \%20Development Plan.NSDP 0.pdf

Smit, B., \& Wandel, J. (2006). Adaptation, adaptive capacity and vulnerability. Global Environmental Change, $16(3), 282-292$.

Su, Y.-P., Hall, C. M., \& Ozanne, L. (2013). Hospitality industry responses to climate change: A benchmark study of Taiwanese tourist hotels. Asia Pacific Journal of Tourism Research, 18(1-2), 92-107.

The Ministry of Environment, MOE. (2002). Cambodia's initial national communication: Under the United Nations Framework Convention on Climate Change (pp. 1-57). Phnom Penh, Cambodia. Retrieved from http://unfccc.int/resource/docs/natc/khmnc1.pdf

The Ministry of Tourism (MOT). (2010). National Tourism Policy of Cambodia. Royal Government of Cambodia.

The Royal Government of Cambodia (RGC). (2006). National Adaptation Programme of Action to Climate Change (NAPA). Phnom Penh, Cambodia. The Ministry of Environment.

The United Nations World Tourism Organization (UNWTO). (2014). Responding to Climate Change Tourism Initiatives in Asia and the Pacific. the World Tourism Organization (UNWTO).

UN. (2017). List of Least Developed Countries (as of June 2017). United Nations Committee for Development Policy Development Policy and Analysis Division Department of Economic and Social Affairs. Retrieved from https://www.un.org/development/desa/dpad/wp-content/uploads/sites/45/publication/ldc_list.pdf

UNWTO. (2016). UNWTO Tourism Highlights 2016 Edition. Retrieved from http://fac.ksu.edu.sa/sites/default/files/tourism_highlights_2016-_unwto.pdf

Walmsley, A. (2012). Climate Change Mitigation and Adaptation in the Hospitality Industry. In Trends and Issues in Global Tourism 2011 (pp. 77-91). Berlin, Heidelberg: Springer Berlin Heidelberg. https://doi.org/10.1007/978-3-642-17767-5_9

World Meteorology Organization, United Nations Environmetal Program, \& World Tourism Organization (Eds.). (2008). Climate change and tourism: responding to global challenges. Madrid: World Tourism Organization.

World Risk Report. (2012). Focus: Environmental Degradation and Disasters. United Nations University (UNU), Institute for Environment and Human Security. Retrieved from

http://www.droughtmanagement.info/literature/UNU_world_risk_report_2012_2012.pdf 
WRI, Oxfarm, \& UNEP. (2011). Adapting for green economy: Companies, communities and climate change (A Caring for Climate Report) (pp. 1-72). Retrieved from http://pdf.wri.org/adapting_for_a_green_economy.pdf

Yusuf, A. A., \& Francisco, H. (2009). $\bar{C}$ limate $\bar{C}$ hange Vulnerability Mapping for Southeast Asia. Economy and Environment Program for Southeast Asia (EEPSEA). Retrieved from https://www.idrc.ca/sites/default/files/sp/Documents\%20EN/climate-change-vulnerability-mapping-sa.pdf 